\section{The view from above: designing from the air Anthony Vidler}

VIDLER, A. The view from above: designing from the air. Thésis, Rio de Janeiro, v. 1, n. 1, p. 28-43, jan/ jun. 2016

\begin{abstract}
Anthony Vidler tem graduação em arquitetura, Universidade de Cambridge, Inglaterra, Ph.D. em História e Teoria da Arquitetura, Universidade de Tecnologia, Delft, Holanda. É Professor Titular (desde 1997) e Decano (2002 - 2013) da Escola de Arquitetura Irwin S. Chanin, The Cooper Union. Historiador e crítico de arquitetura moderna e contemporânea, com foco na arquitetura francesa desde o Iluminismo até a atualidade, vem consistentemente ministrando cursos em projeto, história e teoria. Recebeu prêmios da Fundação Guggenheim e da Fundação Nacional para as Humanidades, nos EUA. Dentre suas principais publicações destacam-se Claude-Nicolas Ledoux: Architecture and Social Reform at the End of the Ancient Regime (MIT Press, 1990), Prêmio Henry-Russell Hitchcock da Sociedade de Historiadores de Arquitetura Norte-Americana. Vidler é membro da Academia Americana de Artes e Ciências (EUA) e recebeu o prêmio de arquitetura desta academia em 2011.
\end{abstract}

\section{Resumo}

Este artigo discute a questão do "planejamento do alto" por meio de dois aspectos: a tradição das vistas aéreas, cuja origem remete ao Renascimento, e que sempre foi um ponto de vista favorito do arquiteto, e a maneira pela qual esta tradição foi radicalmente modificada por duas invenções tecnológicas - a "máquina de voar" e a câmera fotográfica. Examina também como esta forma de ver e representar foi utilizada por Le Corbusier e outros arquitetos modernos, e como permanece até os dias de hoje, e conclui analisando um dos mais célebres mestres da vista aérea - Rem Koolhaas.

Palavras-chave: Le Corbusier; Rem Koolhaas; paisagem.

\begin{abstract}
This article addresses the issue of "planning from above" from a double point of view: the tradition of aerial views stemming from the Renaissance and always a favored view point for the architect, and the way in which this tradition was radically modified by two technological inventions - the "flight machine" and the camera. It examines how it was employed by Le Corbusier and other modern architects and how it has influenced planners and remained so up to today. It concludes by looking at one of our most celebrated aerial masters - Rem Koolhaas.
\end{abstract}

Keyword: Le Corbusier; Rem Koolhaas; landscape.

\section{Resumen}

Este artículo aborda el tema de la "planificación desde arriba" desde dos aspectos: la tradición de vistas aéreas, cuyo origen se remonta al Renacimiento, y siempre ha sido uno de los puntos de vista favoritos del arquitecto, y la forma en que esta tradición se ha cambiado radicalmente por dos inventos tecnológicos, la "máquina voladora" y la cámara fotográfica. También examina cómo se utilizó esta forma de ver y representar por Le Corbusier y otros arquitectos modernos, y cómo se mantiene hasta nuestros días, y concluye analizando uno de los más célebres maestros de la vista aérea - Rem Koolhaas.

Palabras claves: Le Corbusier; Rem Koolhaas; paisaje. 
I $\mathrm{n}$ a recent essay on Brazilian modern architecture, Anna Mainoli, whose recent book on Lina Bo Bardi has served to bring this important architect to new attention, noted two aspects of the urban landscape that fascinated Le Corbusier in his proposals for Rio, and two drawings that he later published in Précisions. First, the horizontal - the horizon's geometry - that as she wrote offered "a poetic confrontation with the panorama" of the landscape and second, the view from the interior through the horizontal window, allowing contemplation of this panorama.

These two aspects have also been commented on by the historian Beatriz Colomina, who pointed out that in this way the building, opening to the panorama, was itself a kind of camera - a comparison to which we shall return. But looking at the drawings examined by Manioli, a third aspect of this viewing position seems to dominate the other two: the aerial view.

It is this view, as employed by Le Corbusier and other modern architects that I want to speak about this afternoon. For this, as we know, was the privileged point of view of the planner and has remained so to today - I will conclude by looking at one of our most celebrated aerial masters - Rem Koolhaas.

In this talk, I want to address the question of "planning from above" from a double point of view: (1) the tradition of aerial views stemming from the Renaissance and always a favored view point for the architect, and (2) the way in which this tradition was radically modified by two technological inventions - the "flight machine" and the camera. I say "flight machine," because the camera, of course, anticipated the airplane by half a century, and the balloon proved an early companion in the emergence of aerial planning. Now the aerial view has of course, in the form of the bird's eye view, been a convention of urban pictorialism since the Renaissance.

Jacopo de Barberi's view of Venice in 1500 is a notable case in point, and the convention was followed by many topographers, map makers and scenographers throughout the next three centuries: indeed a large number of what we might mistake for "maps" are in fact oblique perspective views. 
Take as an example the celebrated map drawn by Madeleine de Scudéry to plot the ways that men might vie for her friendship in the mid-17th century. Here the oblique projection is used to place us in the picture, to envisage what might be a map as a landscape to be traversed - a number of utopian "maps" were treated in the same way - notably Holbein the elder's depiction of More's island of "Utopia."

But sometime in the early 18 th century there was a radical shift, not so much in the conventions of representation but in the instrumentality of the bird's eye view: the evidence is provided by the enormous success of the novel Le diable boiteux by Alain-René Lesage. The decisive moment occurs at the outset of the narrative. Says the devil to the student:

"I plan to show you from this high vantage-point everything that is happening in Madrid at this moment. By means of my diabolical power I am going lift up the roofs of the houses and, despite the shadows of the night, I want to uncover the insides to your eyes without veil. At these words, he simply extended his right hand, and immediately all the roofs seemed to be lifted. Then the student saw, as if in full daylight, all the interior of the houses."1

The power to lift up the roofs and discover the private world of the inhabitants of the city was in every way an assertion of the objective, socially precise, and knowledge-seeking view appropriate to a rational philosophe - and of course to the emerging discipline of urban planning. Vision and surveillance, as Michel Foucault pointed out a long time ago, became one and the same thing.

For with the magical gesture opening up the roofs of Madrid, the little devil also appealed to those who believed that a rational architecture and urbanism, opened up to light, air, and the free circulation of people and goods, would materially assist the work of enlightenment; would of their own mechanisms of transparency effect the good society. The tearing away of the roofs became a symbol for the removal of all barriers to sight - a favorite motif of planners from Pierre Patte in the 1760 s to Haussmann a century later. The modern technologies of iron and glass made the analogy even more literal, and the transparent city as we know it in modernism from Le Corbusier to the present is clearly the heir to such ideals.

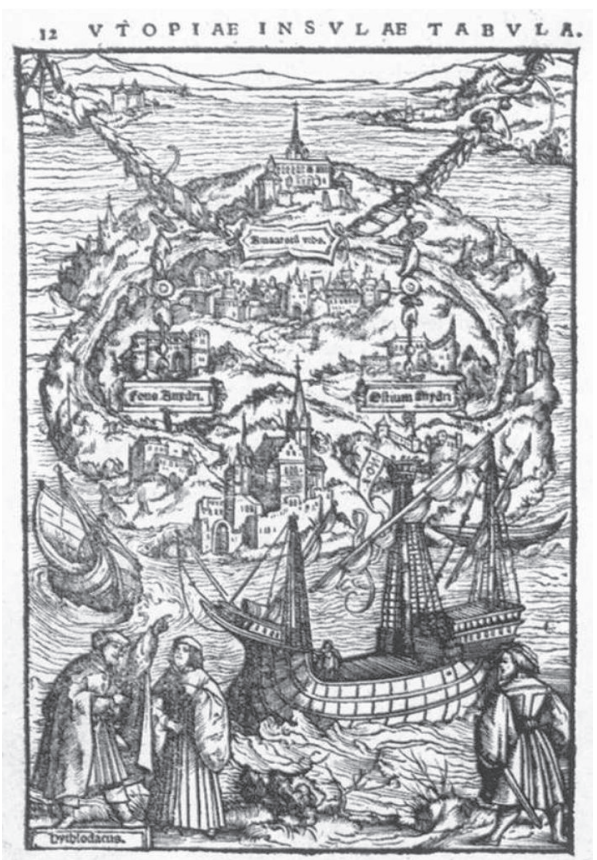

Figura 1

The Island of Utopia, by Ambrosius Holbein, 1518 .

1 Alain-René Lesage. The Devil on two sticks (original, Le diable boiteux, 1707) translated by Joseph Thomas, (Ex-classics Project, 2010). 


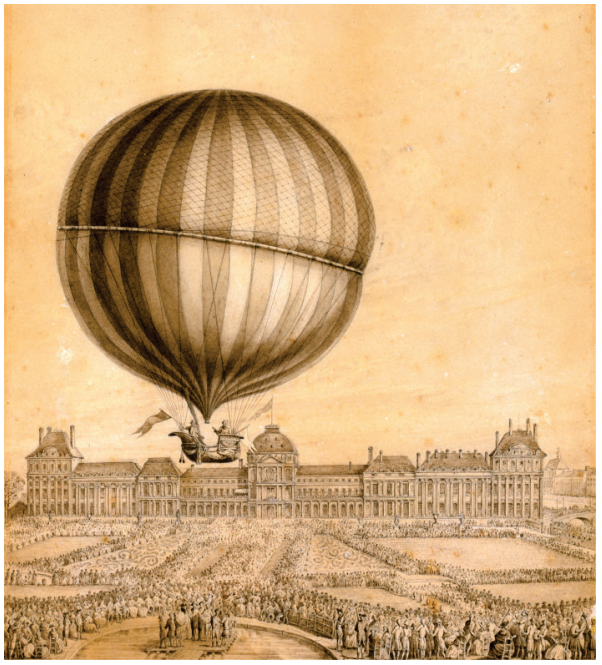

Figura 2

Contemporary illustration of the first flight by Prof. Jacques Charles with Nicolas-Louis Robert, December 1, 1783. Viewed from the Place de la Concorde to the Tuileries Palace (destroyed in 1871).

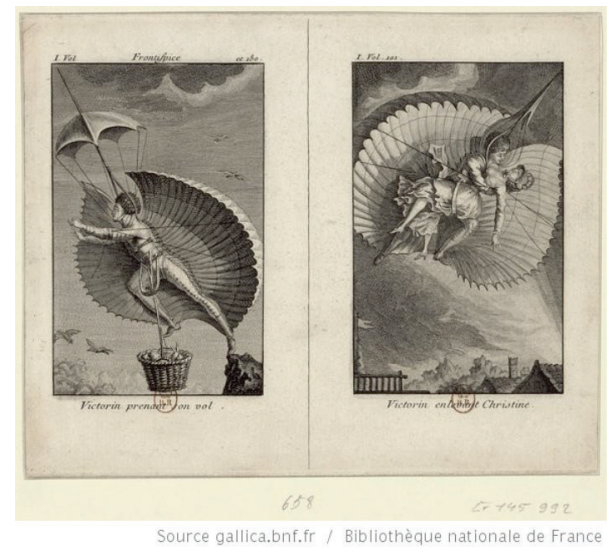

Figura 4

Restif de la Bretonne "La Découverte australe par un homme volant ou le Dédale français" (1781)
If the devil on sticks had transformed the bird's eye view into an instrument of sociological inquiry and planning efficiency, it was the actual balloon ascension of the Montgolfier brothers in 1784 that transformed a potential and virtual vision into a reality.

Even more prescient was the flight of Jean-Pierre Blanchard in the same year, using propellers and in 1785 crossing the Channel from Dover to France. Thus when the architect Etienne-Louis Boullée proposed a symbolic monument to Newton's genius in 1785, everyone recognized the balloon within the sphere;

And when Ledoux engraved his celebrated view of his Ideal City of Chaux, that he imagined growing up

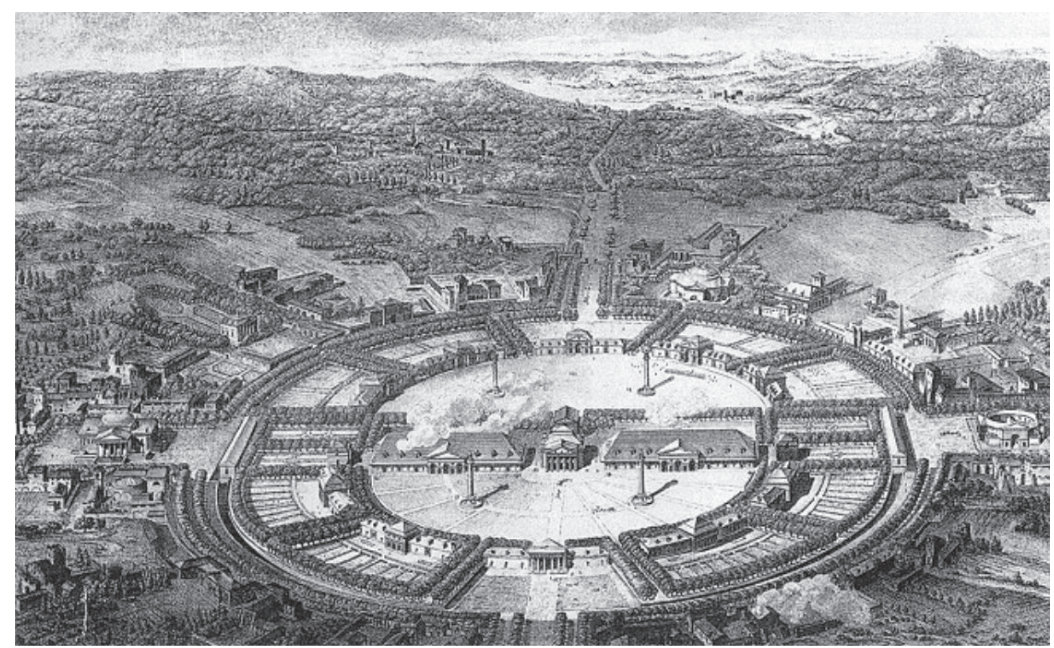

Figura 3

Claude-Nicolas Ledoux, The Ideal City of Chaux, 1804.

around the Saltworks he had built at Arc-et-Senans, he was evidently endowing the architect with the powers of sight, and thereby vision, of the aeronaut.

Rétif de la Bretonne followed with his proto-science fiction images of flying machines;

Victor Hugo offered a "bird's eye view" of Paris in Notre Dame.

Such depictions of the city were of course essential in the universe of capitalist speculation, and thus essential in the structuring of Baron Haussmann's "improvements."

Views of Paris from above, famously those of the new boulevards cut by Haussmann were henceforth proposed as the "planner's view," and this view, in turn, 
emerging as the privileged position from which planning, always an activity of abstraction, had to be carried out.

If the balloon allowed planners and policy makers a real-life view of the field of their speculation, it was the camera that transformed this view into a working document for planning itself. It was the photographer Nadar, fascinated with the underbelly of Paris - the new sewers - who first ascended above Paris in his own balloon, Le Géant, camera in hand.

This aerial camera, first deployed by Nadar in 1858, so as, as a cartoonist had it, at last raised "photography to the heights."

This led to many other flights, from the tethered balIoon over the Trocadéro in the Exposition of 1867 and culminating in his work for the Commune in 1871, where he managed to fly over the enemy lines with dispatches several times, mulling the senses of the German artillery with champagne thrown out of the basket at appropriate intervals.

This new media had two immediate consequences. The first was a sense of distancing, coupled to a sense of power, over the habitations of the citizens. As Siegfried Kracauer was to remark much later, "Photography shows cities in aerial shots, brings crockets and figures down from the Gothic cathedrals. All spatial configurations are incorporated into the central archive in unusual combinations which distance them from human proximity." ${ }^{2}$ As Kracauer noted, the aerial viewpoint, entirely distanced from the ground, tended necessarily to increase the natural "distance" inherent in the photographic medium, and thus to increase its assumed objectivity and of course its inherent manipulability devoid of the difficult and intractable individual or social subject. ${ }^{3}$

Secondly, and perhaps joined to the first in a diabolical compact with urban planning, in the evident utility of manned flight for reconnaissance and war, there emerges a new and disturbing implication to the aerial view. What previously had seemed an innocent enough, if not triumphal view of urban progress, and visual survey, was transformed into an instrument of surveillance and worse, attack from above. The balIoon and its vision had become a new diable. As Jules Verne intimated, the power of flight was a double bind: in Robur-le-Conquérant the engineer glides over Paris with searchlights, and over the "savages" with bombs.

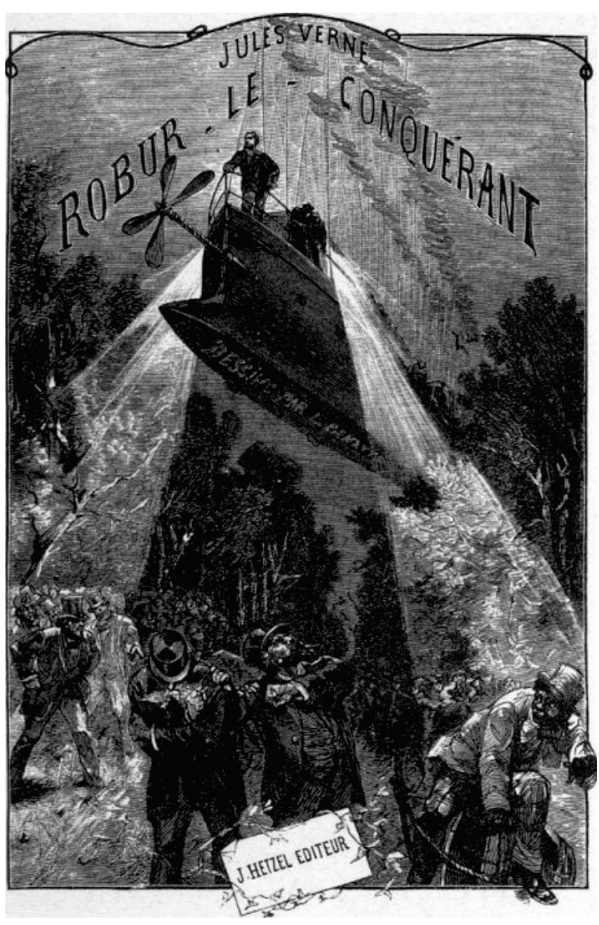

Figura 5

"Robur the Conqueror" drawn by Léon Benett.

2 Sigfried Kracauer, The Mass Ornament: Weimar Essays, (Cambridge, MA: Harvard University Press, 1995).

3 Ibid., p. 62

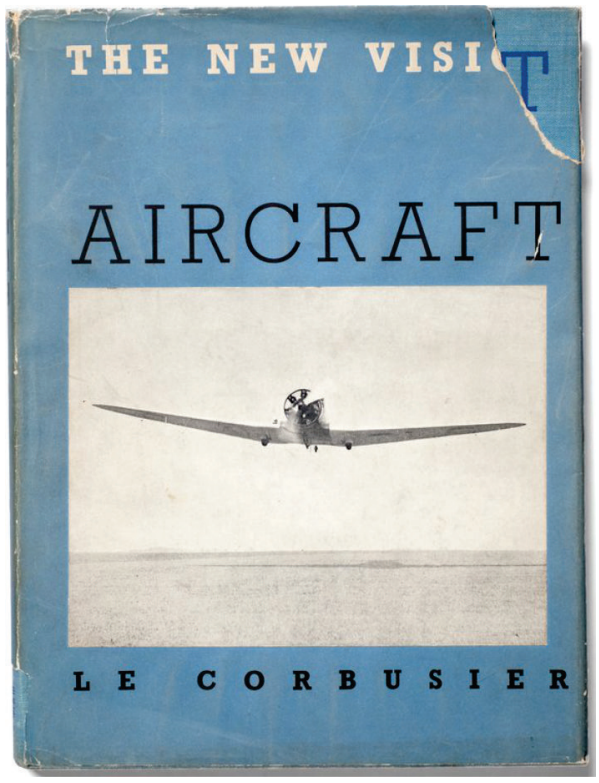

Figura 6

Le Corbusier, Aircraft. «L'avion accuse....». By Le Corbusier. - London, New York- The Studio 1935 
4 Bruno Pedretti, Il volo dell'etica. Casabella 531-2 (January - February, 1987): $74-80$

5 Bruno Pedretti, Il volo dell'etica. Casabella 531-2 (January - February, 1987): $74-80$
The complicity between planning and bombing was thus well established at the moment of technological modernism and was well recognized even by those who proposed flight as the modernist-planning tool par excellence. It is well known that Le Corbusier had a love of airplanes: the illustrations and text of Vers une architecture, his sketches of Latin America from the air, his photographic album Aircraft published by Studio in 1935, are only a fraction of the instances when his "complexe de Saint Exupéry" was unequivocally demonstrated. ${ }^{4}$ Thus Le Corbusier, whose enthusiasm for flight was, as he recalled later, provoked by hearing the roar of Le Comte de Lambert's aircraft passing over his student garret in the Quai Saint Michel in 1909 ["I heard a noise which for the first time filled the entire sky of Paris. Until then men had been unaware of one voice only from above - bellowing or thundering - the voice of the storm."], proclaimed "Wars are finished: no more wars are possible! There are no longer any frontiers!" only to admit, following the experiences of the First World War and the threat of the Second, "the bird can be dove or hawk. It became a hawk. What an unexpected gift to be able to set off at night under cover of darkness, and away to sow death with bombs upon sleeping towns (...) to be able to come from above with a machine-gun at the beak's tip spitting death fanwise on men crouched in holes." ${ }^{5}$

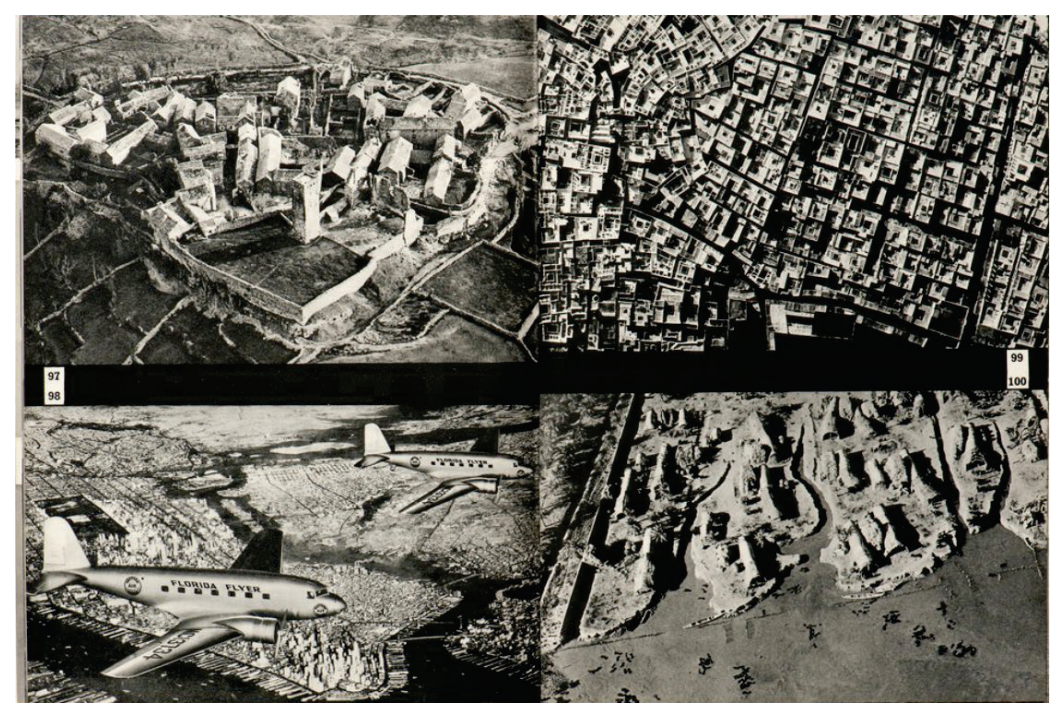

Figura 7

Le Corbusier, Aircraft. «L'avion accuse...».:

By Le Corbusier. - London, New York- The Studio 1935

Bombing was also, as many planners were to remark during and after the Second World War, a very useful instrument of clearance. 
Evertheless, the aerial view, if not actual aerial vision, became a part of Le Corbusier's representational and conceptual technology: "I place myself, from the point of view of architecture, in the state of mind of the inventor of airplanes" ${ }^{6}$ he wrote in 1923, finding aesthetic and functional lessons in airplanes that might be used in houses - after all, he noted, the airplane is only a flying house, and the house a static airplane.

His developing theory of urbanism on the other hand, figured the airplane as a technique and visual instrument of planning. It was what the airplane revealed as a visual instrument, equivalent to the camera, the telescope and the microscope that made it important.

Thus in his representation of the 1923 project for a Ville Contemporaine, the diorama, so powerful a vehicle for the representation of the nineteenth century metropolis, is now added to the aerial view as the preferred representational device for the big city plan, a plan which is among the first to embed an airport at its center, significantly enough in the form of Saint Peter's Rome. Even seated on a café-terrasse the inhabitant is not far from airplanes.

The photographic evidence for the new scale of the city is equally aerial: "At the same scale and at the same angle, view of the Cité of New-York and of the Cité of the 'Ville Contemporaine.'

"The contrast is striking," he concluded. ${ }^{7}$

Le Corbusier had selected an aerial photo made from a balloon flight in 1909 of the Eiffel Tower for the cover of L'Art Décoratif d'aujourd'hui, a photograph that had already served Robert Delaunay for his painting of 1922, Le Tour Eiffel, and in Urbanisme such views from the Eiffel Tower are used to simulate views from the office windows - "From these office windows will come to us the feeling of look-outs [vigies] dominating a world in order." 8 Other aerial photos are used, again to draw scale comparisons: two photos in particular, taken from the collection of the Compagnie Française Aérienne, show, respectively, the quarter of the Archives, and the quarter of the Champs Elysées. They are compared with respect to the urban conditions they reveal. The captions read:

"Is this a view of the seventh circle of Hell of Dante? No, alas, it is the terrifying shelter (gîte) of hundreds of thousands of inhabitants. The City of Paris does not possess these denouncing photographic documents.
6 Le Corbusier, Vers une architecture, (Paris: Éditions Crès, Paris, 1923), p. 85.

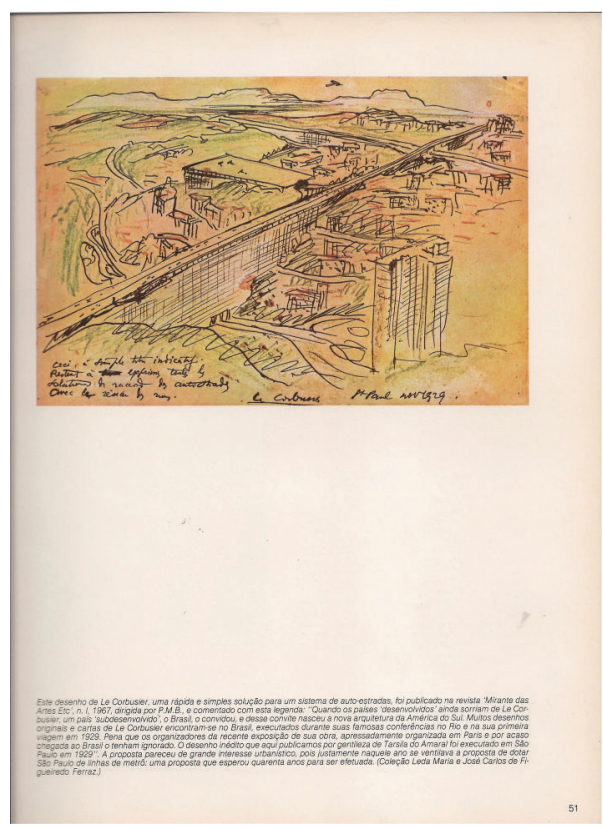

Figura 8

Propostas de Le Corbusier para São Paulo e Rio de Janeiro realizadas em 1929 (São Paulo) e 1929-1936 (Rio de Janeiro) publicadas nas páginas 50,51 e 73 do livro: BARDI, P. M. Lembrança de Le Corbusier: Atenas, Itália, Brasil. São Paulo: Nobel, 1984.

7 Le Corbusier, Urbanisme, (Paris: Éditions Crès, 1925), p. 164.

8 Ibid., p. 177.

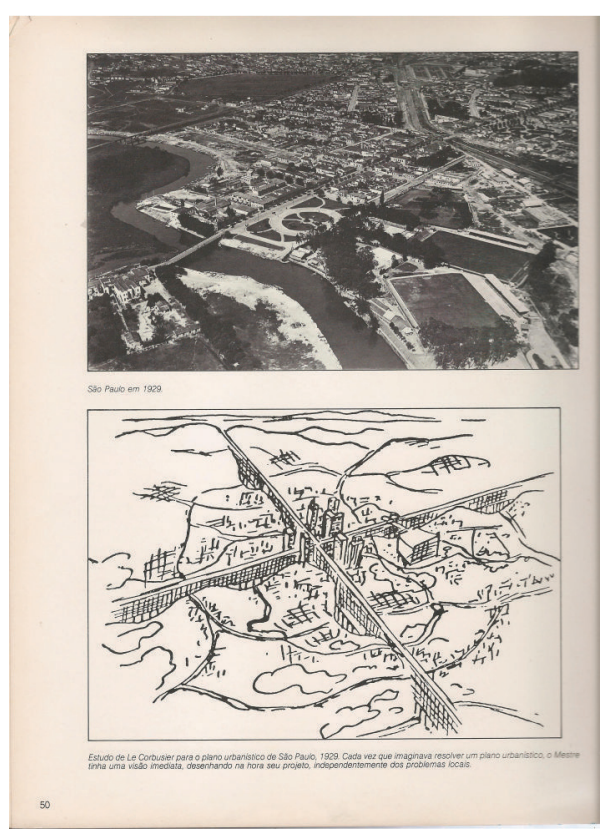

Figura 9

Propostas de Le Corbusier para São Paulo e Rio de Janeiro realizadas em 1929 (São Paulo) e 1929-1936 (Rio de Janeiro) publicadas nas páginas 50, 51 e 73 do livro: BARDI, P. M. Lembrança de Le Corbusier: Atenas, Itália, Brasil. São Paulo: Nobel, 1984. 


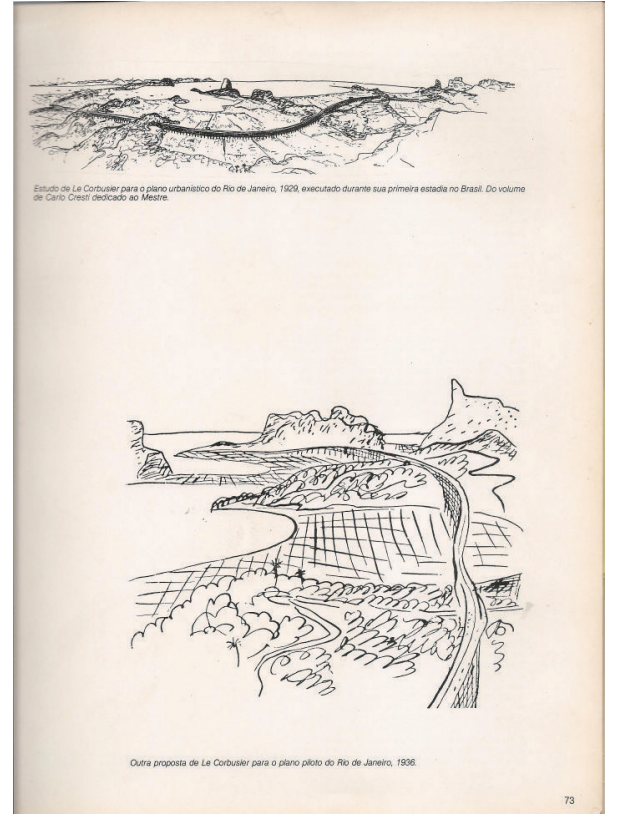

Figura 9

Propostas de Le Corbusier para São Paulo e Rio de Janeiro realizadas em 1929 (São Paulo) e 1929-1936 (Rio de Janeiro) publicadas nas páginas 50, 51 e 73 do livro: BARDI, P. M. Lembrança de Le Corbusier: Atenas, Itália, Brasil. São Paulo: Nobel, 1984.

9 Ibid., p. 268
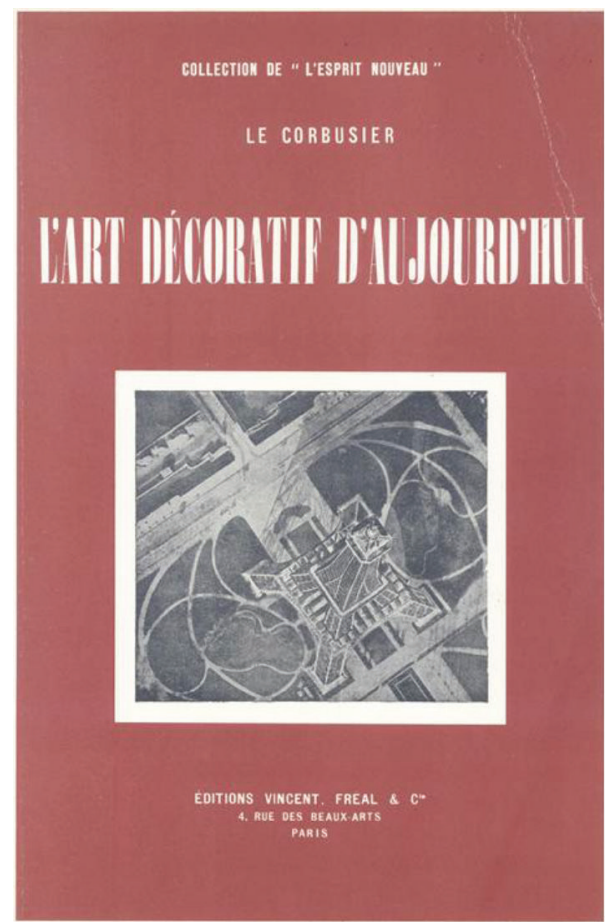

Figura 11

Propostas de Le Corbusier para São Paulo e Rio de Janeiro realizadas em 1929 (São Paulo) e 1929-1936 (Rio de Janeiro) publicadas nas páginas 50, 51 e 73 do livro: BARDI, P. M. Lembrança de Le Corbusier: Atenas, Itália, Brasil. São Paulo: Nobel, 1984.
This view of the whole (vue d'ensemble) is like a sledge-hammer blow."

The aerial photograph is now an instrument of battle, a legal submission in a trial over the proper nature of urban space. For Le Corbusier only an aerial photograph reveals the whole truth, shows what is invisible from ground level, and demonstrates the case against overcrowding decisively. The final "blow" of the Corbusian sledgehammer is to juxtapose the aerial view of the proposed area of redevelopment, the Marais, against the plan for renewal at the same scale. ${ }^{9}$

The martial analogy is apt enough, for of course it was as an instrument of reconnaissance that the airplane photo came into its own in 1914-1918. Gradually, as the war developed aerial bombardment and aerial surveillance became indissolubly linked.

At the start of hostilities, a camera found in the wreckage of a captured German Zeppelin inspired the French to set up a photographic corps under the Armée de l'air, with the help of a former professor of photographic science at the University of Paris, Louis-Philippe Clerc. Together with a new aerial intelligence section of the Service Géographique de l'Armée under General Bourgeois, these two services thenceforward became the primary source of aerial images, classified and popular, well into the 1920s. Towards the end of the war, the development of military information began to support new archeological studies. In Syria, archeologists from France and Britain, themselves formed in aerial reconnaissance, started to use "aerial discovery photography," in their surveys.

This combination of the military and the urban, not new in the politics of replanning Paris since Haussmann, was consolidated by Le Corbusier in La Ville Radieuse, published in 1933 and written after his own flight to Moscow.

The Radiant City itself was not simply conceived from the air; it was also conceived with a view to its survivability under aerial attack, sensed to be an increasing danger in the 1930s. Citing the evidence of French and German military strategists - Lt. Col. Paul Vauthier, Le danger aérienne et l'avenir du pays (Paris, 1930) and Dip. Ing. Hans Schoszberger, Bautechnischer Luftschutz (Berlin, 1934) - Le Corbusier argues for the Ville Radieuse as defensible space - defensible that is from air attack. Against the "sinister apotheosis" heralded by aerial warfare, Le Corbusier argued that the type of city "Ville Radieuse," would, with its thin ribbons of buildings offering little surface for bombardment, 
its concrete flat roofs offering shelter-like protection, its air conditioning and elevation on pilotis protecting against poison gases, and its open parkland in which bombs might drop harmlessly, be the only kind of city "capable of emerging victorious from an air war."10

Looking back in 1964 Le Corbusier remembered that Saint-Exupéry had warned him: "Be prepared M. Le Corbusier; the airplane has now endowed man with an eye that can look down from 12,000, from 30,000 feet above the ground." Le Corbusier retorted, accurately enough as we have seen, "For years I have been using an eye that is 30,000 feet above the ground!" The architect was now endowed with "A new eye: the eye of a bird transplanted into the head of a man. A new way of looking: the aerial view. What the rational intelligence had acquired in the way of knowledge by analysis, by comparison, by deduction, suddenly becomes a matter of total and first-hand experience for the eye. And to see is a mode of perception unutterably more forceful than simply conceiving with the brain."11

Such an eye was, of course, not simply a surveying eye, but also a surveillance eye. The ethnologist Marcel Griaule, who had led the expedition to study the Dogon in 1936 underlined this in his eulogy of aerial photography to the Paris geographical society:

"De toute évidence les documents qu'elle établit constituent des instruments de travail de premier ordre pour l'Administration coloniale: gouverner un peuple, c'est d'abord le connaître. ... les études de l'ethnologie aidera, par le fait même, les gouvernements coloniaux dans l'exercice d'une tâche difficile et aux multiples aspects." ${ }^{12}$

A means of understanding the indigenous population, of course, but also as colonial oversight.

By means of aerial photography Griaule was able to survey the territory of the Niger, the land of the Dogons, with the help of the Air Ministry and the military air arm of Gao, in a third of the time that a land survey would have cost.

All this, for Le Corbusier came together in his first real experience of flight over a wide territory, on his trip to Brazil in 1929. Beatriz Colomina has described Le Corbusier's first real experience of flight, and the effects on his planning strategies:

"On his first trip to South America in 1929, Le Corbusier took his time, traveling by
10 Le Corbusier, La Ville Radieuse, pp. 60-1

11 Corbusier, Précisions: Sur un état présent de I'architecture et de lourbanisme (Paris: Vincent, Fréal et Cie, 1930) p. 83

12 "It is fully apparent that the documents it establishes constitute working tools of the first importance for the official administration: to govern a people is first to know it ... studies in ethnology will help, by the same token, colonial governmentin the exercise of a difficult task with different aspects" (Marcel Griaule, L'emploi de la phtographie aérienne dans la recherche scientifique, L'Anthropologie, 1837), pp. 474-5. 
13 Beatriz Colomina, "Towards a Posthuman Architect," In: http://www. design-in-human.de/symposium/colomina.html.

14 Emmanuel de Martonne, Geographie aérienne (Paris: A. Michel, 1948), p. 15.

15 Paul-Henri Chombart de Lauwe (ed.), La découverte aérienne du monde (Paris: Horizons de France, 1948), p. 19-56.

16 Michel Parent, "L'utilization de la photographie aérienne para l'urbaniste". (In: La découverte aérienne du monde), pp. 316-26.

17 Ibid., p. 316. ocean liner to Montevideo and Buenos $\mathrm{Ai}$ res, and then mostly by plane-accompanied by such pioneer aviators as Jean Mermoz and Antoine de Saint-Exupéry-staying from September to December in Buenos Aires, São Paulo, and Rio de Janeiro. It was on this first trip that he developed the first sketches for the plan for Rio de Janeiro-60 kilometers of elevated highway with housing underneath. He returned in 1936, traveling in the Graf Zeppelin between Frankfurt and Rio de Janeiro via Recife. The flight was 68 hours to Recife alone. Oscar Niemeyer described him arriving like a god, first to step off the Zeppelin, after a rough landing that had worried the local architects eagerly waiting for him in the hangar". ${ }^{13}$

This, of course did not stop Le Corbusier from walking, and even taking a swim. I will not go into detail on Corbusier's plans for Rio - they are well enough known, and the often neglected work, Précisions, gives very important insights into his thought processes as he sketched.

With the close of hostilities in World War II, and with the enormous advances in technology stimulated by military reconnaissance in 1941-45, the aerial view became institutionalized as a central tool of planning, and, in France, largely through the efforts of Paul Chombart de Lauwe, a geographer and ethnologist CNRS, attached to the Musée de I'Homme, who had himself crossed the Sahara in a tourist plane to aid the mission ethnographique of Griaule in 1936 and who was dubbed "le pilote ethnographe," as he fought in the Free French Army from 1942-45. ${ }^{14}$ Writing in 1948 in his edited volume La découverte aérienne du monde (Paris: Horizons de France, 1948) Chombart claimed "La vision aérienne du monde," as the vision of modernity. ${ }^{15}$ In the same volume Michel Parent, conservateur du Musée des plans en relief, wrote on "L'utilisation de la photographie aérienne par l'urbaniste," both as a tool to criticize Haussmannisation, and as a way to celebrate the three dimensional modernity of Le Corbusier's visionary whose spatial slogans and representations he notes, are derived from aerial photography. ${ }^{16}$ "The aerial view of the center of Paris," wrote Parent, "demonstrates to what extent Haussmann was led to disembowel the old quarters, to sometimes denature sites that the centuries had patiently harmonized."17 This did not prevent him from eulogizing the projects of Le Corbusier, who had succeeded, he claimed, in realizing the perfect inter- 
section of the "aerial vision and three-dimensional urbanism," against what he called "mole urbanism," the view from too close to the ground.

Turning from the territory as a whole, to the city of Paris, Chombart, in a work that greatly influenced the Situationists after 1958, found that one of the best forms of documentation not only of the physical milieu, but also of social processes, was the aerial survey:

"In the study of social space, an important part of its explication is linked to aerial views and graphic documentation. The aerial survey and research by comparative maps allows, not only the representation of the social space, but also the study of certain processes."18

The aerial view of a city, indeed, is, in Chombart's terms, the only means of developing a synthetic vision of its social space, - "I'espace social" - which is the theme of the first part of his Paris study, a work influenced strongly by Maurice Halbwachs.

It seems in this context somewhat paradoxical that Guy Debord and the Situationists will turn to Chombart's aerial analyses in their attempt to map what they see as a potential new "psychogeographical" urban order that will undermine and confront the distanced vision of the modernist planners. Against Le Corbusier, symbol of the alienation of contemporary modernity, Debord sought to reformulate the aerial view on his own terms, as a technique that, so to speak in the Situationist vocabulary, might be détourned for his own purposes. Thus he uses several photos of Paris from above taken from Chombart, as well as Chombart's surveys of everyday life in the city.

Interested from his schooldays in the methods and representational strategies of cartography, Debord developed a complex theory of mapping based on his reading of Madeleine de Scudéry's celebrated Carte de Tendre, a map we have seen before.

In the article "Unitary Urbanism at the end of the Fifties," published in the third number of the Internationale Situationiste. He reproduced Carte de Tendre side by side with an aerial view of Amsterdam.

The juxtaposition of the Carte de Tendre with the aerial photograph of Amsterdam - the selected "experimental zone" to be "systematically explored by the Situationist teams" in a dérive planned for April-May
18 Paul-Henri Chombart de Lauwe, Paris et l'agglomeration parisienne, (Paris: PUF, 1952), vol. 2, p. 5. 
19 Vincent Kaufman. Guy Debord: Revolution in the Service of Poetry. (Minneapolis: University of Minnesota Press, 2006).

20 Blaise Pascal, Discours sur les passions de l'amour (1652-1653).
1960 - implies not only that "Amsterdam" is considered a realm of the passions and a site of heroic passages along water ways that resemble those of the realm of Tenderness, but also that such an action will in some sense "return" the city to a counter-urbanist state, one closer to the Precieuses than to Descartes.

More directly, the effect of the Carte de Tendre is manifested in the collage map of Paris constructed by Debord in 1956 under the title "Guide psychogéographique de Paris," and published in Denmark by Jorn in the series of the new "Bauhaus Imaginiste."

Vincent Kaufmann has termed it "another carte de Tendre (or more precisely the first one)," and pointed to the sub-title of the map: "Discourse on the Passions of Love." 19 This, of course, joins the map as a symbolic return to the celebrated essay, attributed to Pascal, also entitled Discours sur les passions de I'amour. ${ }^{20}$

Even more intriguing, was the choice of the map of Paris, the pieces of which formed the collage. Rather than in the almost contemporary map "Naked City," cut up from the standard map of Paris by arrondissement, the "Guide Psychogéographique" selected a bird's-eye view, meticulously drawn by G. Peltier and published by Blondel la Rougery in 1951.

Consciously modeled on the celebrated Turgot map of Paris (1739), it showed the city in perspective, at an angle roughly equal to the point of view established for the Carte de Tendre. This oblique view, as opposed to the geometrical survey of the map, offered a sense of place, space, and buildings analogous to the aerial photograph, allowing for the viewer an imaginary entry into the urban fabric. As Chombart wrote in the technical notes to his sociological study Paris et I'agglomeration Parisienne,

"oblique photos allow one to have views of the same sector taken from different sides. They provide, further, views plunging onto the facades of houses, and into the interior of courtyards, which are indispensable for sociological studies."

But the Situationists, in the years of a colder and colder cold potentially nuclear war, were also sharply aware of the more diabolical side of the aerial perspective. Two images from the Situationist International make the point.

The first "illustrates" an announcement of the upcoming Fourth Conference of the International Situationist 
in London, planned for September 1960, and shows a B52 Bomber photographed from above, dropping its bombs on an unspecified city.

The second reproduces a "thermonuclear map" constructed by the artists J.V. Martin, in a series of "cartographies" made out of pop-art images, and representing different regions of the world during a Third World War (or what the SI termed "the" third world war.). Entitled "Europe 4 hours after the beginning of the $3^{\text {rd }}$ world war," it shows a map of Europe, made up of a collage of charred paper in relief; an image of a burned out and destroyed world. This series of maps was joined with a reconstruction of a nuclear fall-out shelter, in a manifesto protesting the Danish government's construction of a secret shelter.

After the mid-60s the aerial view disappears from the SI: under the threat of nuclear annihilation from the skies, the Situationists evidently decide to wage war on the ground and in the streets. Debord, however, will still feature aerial images in his films, but now images that signify his quasi-retreat into nostalgia, as reminders of an old Paris now irretrievably destroyed by modern development. These views reoccur again and again in his films, used as stills, or as simulated flights over the city, panning over the stills, memory devices, even as the Paris of the early 1950s, site of the first delirious dérives changed rapidly into an unknown and alien territory, a change that, Debord laments, echoing Baudelaire, is more rapid than that of the human heart. Where Sur le passage de quelques personnes à travers une assez courte unité de temps (1959) preferred to work with stills of Les Halles and the surrounding streets on the ground, beginning with Critique de la séparation (1961), the aerial view is inserted almost insistently; the Place de la Concorde, viewed from a helicopter, the view of the Seine, the panned view of the center of Paris, the quai d'Orléans, the island of Cygnes, are interspersed with photographs of the Situationists themselves, their cafés, and cut by images of old and new wars.

The aerial view will return obsessively in the final film In girum imus nocte et consumimur igni, that palindrome which returns on itself in self-consumption, where the Paris of his 1950s will be viewed from above, zoomed into and framed with tender care panning across aerial photo-stills, that incessant "series of different aerial photographs of Paris" traversed in movement. In looking, with Debord, through the lens of In girum imus nocte, we are reminded of a similar return to childhood utopia in the escape of another 
"Pascal," from the ugly streets of working-class Paris, in Albert Lamorisse's Ballon Rouge (1956) as he finally ascends over Paris on the strings of the community of balloons.

Another architect, younger but still contemporary with and influenced by Debord and his friends, Rem Koolhaas, clearly works with similar images from the outset of his career - his thesis project at the Architectural Association, "Exodus or the Voluntary Prisoners of Architecture," used all these devices, from nostalgia, to terror, and above all to irony, to depict a post-World War III social landscape of self-imprisonment. Surveyed from above society begins to enjoy the spectacle of its own domination.

And, as we know, Koolhaas has not ceased to survey society from the heights of flight - a relatively recent issue of Wired Magazine demonstrated this precisely.

The world is mapped - by theme and then surveyed from the air - the space revealed is then analyzed. And what is revealed is not the optimistic opening up of ineffable space construed by the former generation of modernists, but a dispirited and degraded version of progress stalled, space ruined, a world of detritus and waste, of implosion and explosion.

For Koolhaas, the terms of architecture have simply evaporated, or more properly, become virtual, as they have been adopted, like ghosts, into the terminology of the web and the net: chat rooms, firewalls, web sites, and the like. Architecture, as traditionally conceived in Modernism, is unequal to the task of description of and response to these "entirely new spatial conditions." For Koolhaas, modernism, or rather the paranoid-critical response to modernism provided an adequate frame of reference, and an aesthetic paradigm, for architecture conceived as programmatic hybridity in single buildings, or even for the scale shifts of building complexes, or the variety-laden repetition demanded by global consumerism - the architecture that is of the Rotterdam Kunsthalle, the Paris and Bordeaux Houses, EuroLille, and Prada. Koolworld announces the burnout of Modernism as paradigm or anti-paradigm, and the emergence of something not yet clearly delineated - "a fragment of an image, a pixilated map of an emerging world." 21

Space has changed its nature since modernism ruled the world: "our old ideas about space have exploded," writes Koolhaas in a passage reminiscent of Walter Benjamin's characterization of the explosive spatial 
effect of movies. And so, the new spaces are mapped too - euro space, space space, relationship space, boom space, voice space, home space, bush space, protest space, body space, research space, border space, tight space, art space, sex space, crowd space, future space, secure space, color space, blog space, robo space, dna space, ad space, golf space, limbo space, waning space, and finally, public space.

But the spaces celebrated here are, in contrast to the former utopianism of modernism, and of Wired itself in its first iteration, far from ideal. They are the desultory spaces of a world in decay, the end-of-the-line spaces of a modern movement gone very wrong, the threatening spaces of technology run amock, of information unlimited, the totalizing spaces of an ultimate globalism. If the gaze of Koolworld's contributors was less relentless, we would be tempted to use adjectives like "Orwellian" - after all, as William Gibson has recently pointed out, Orwell's "1984" was no more than his own "1948" set in the future for emphasis. Koolworld, however, makes no pretense of a future - it represents the here and now with hyper-objectivity.

And yet, there is also, as with much science fiction, a sense of nostalgia hovering beneath the apparently radical unmasking of present-day dystopia. For, perhaps with the exception of blog space, these spaces, far from new, have been around a long time - at least since the end of the Second World War. Euro space was, after all, the post-War dream; space space, and robo space were long ago extracted from comics and put into orbit; ad space was the fetish of the Situationists; relationship space, home space, and body space were the domains of the new psychology of R.D. Laing and the feel-good warmth of Woodstock. Such spaces were the leitmotivs of Archigram and other so-called utopian groups in the 60s, taking their cue, as Banham noted, from movies like "Barbarella," or in the case of body space, "Fantastic Voyage." And does not "fading space" provoke echoes of Robert Smithson's essays on entropic space (a space left out of Koolworld) in the 70s. And yet, perhaps inevitably, the language deployed to describe this world, is that of Modernism - the language of graphs, maps, charts, and apparent objectification -- not that different from Banham's graphs of past, present, and possible futures, or Jencks' prophesies of "Architecture 2000" (recently updated), or, before them, of Le Corbusier's diagrams of historical progress, his mapped overflights of Brazil, and charted population studies of Paris. Koolhaas, too, still uses the all terminology of space, a terminology with a century of history and infinite qualifications, from the origi-
22 Koolhaas, ibid., p. 137. 
nal spielraum of Wofflinn to the espace indicible of Le Corbusier and the multiple postmodern spaces since the 60s. For Koolhaas, one space has substituted for another - new ways of seeing reveal new spaces (a fundament of Modernist theory. Even "junk space" now upstaged by "dump space," a space apparently escaping from "constraints, from selection, from the tyranny of style," ${ }^{22}$ has been anticipated by the Modernist space par excellence, that of the informe. Koolworld is still a profoundly Modernist world, and one suspects that beyond the bravado and anticipation of the new, the architecture that will undoubtedly emerge to represent this world will also be Modernist at root, and like its predecessors out of Delirious New York, SMXL, and The Harvard Guide to Shopping, entirely contemporary for all that.

In these remarks, I have hoped to suggest that the view from above, used as illustration for urban novels and scenarios from the eighteenth century on, is both ruled by convention and re-formulated by technological invention, and has worked powerfully to reformulate the theory and practice of planning, surveying, and interpreting modern cities. Its relation to the novel, I think, is equally powerful, as the figuration of the engraved or photographic map or aerial view has served as a key to an emerging form of narrative. Much in the same way as what the British call the "it-narrative," or "novel of circulation," was developed out of the form pioneered by Lesage - the devil's story turned into the self-narrated stories of a golden coin, or a bank note common in late eighteenth century France and England, I think it would be possible to detect a variant narrative form in the aerial view. Part picaresque, part aleatory dérive, this would be the narrative of over-flight, one that glides over the surface of the earth, in imagination or reality, in order to reveal the mysteries of habitat, the secrets of habitation. Rather like the role of "voice off" in the movies, the "vision off" of the aerial view remains a potent instrument in the modern novel, recently given new force with the virtual animation of the video screen narrated so evocatively by William Gibson ; perhaps it is only now to be usurped by the random forms implied by the digital surveillance techniques of NSA, in their self-described "vacuum cleaning of the ether." Or, like the diable de Paris in his prefiguring of flight, perhaps even these new forms have already been well defined by novelists like Pynchon. 